\title{
FROM IUS VALACHICUM TO THE VLACH FOLKLORIC INFLUENCES WITHIN CENTRAL EUROPE
}

\begin{abstract}
ARMAND GUTA
ABSTRACT: This short paper aims to show the ancient links between the cultural and occupational migration of the Vlach (Romanian) shepherds and their folkloric influence upon the Central Slavic ethnographic style and folkloric customs. The Vlach shepherds migration began more than 1,000 years ago and it was an ethnic and occupational phenomenon spread over East and North-East Europe and over Central Europe, far away over the River Don to the Caucasian area and through the Balkan Peninsula in Asia Minor. Concerning the Central European medieval laws from the 17th century till the 18th century these Vlach shepherds communities had their old oral Vlach jurisdiction and special rights periodically renewed by the former Hungarian, German and Polish kings. They had an important military function as frontier guards and they participated in the defence of the nobility. From the middle of the 18th century all of the Vlach communities were unde domination but their cultural and folkloric heritage remained in the Central Slavic folklore. Its presence might be especially seen in the songs performed at the beginning of the 20th century. Nowadays these influences are less visible but in the last 120 years many Czech, Polish and Slovak researchers have researched these old folkloric elements and published them into more than 200 abstracts and studies. After the Second World War within the scientific Central Slavic aspect appeared several folkloric studies especially dedicated to all Vlach folkloric influences on today's folklore. The results were unexpected and proved that these Romanic elements were about 500 years old or more and influenced much of the Central Slavic folkloric genre. We cannot make an exception of the hundred ancient Romanian words inherited by today's Slovak shepherds together when many thousands of Vlach ethnographic and folkloric influences lead us towards some interesting conclusions that for a long time the co-existence of the Czech, Slovak and Polish and Vlach population had generated a Slavic-Romanic cultural mix. This genre of the cultural symbioses and its elements are unique in the Central Slavic cultural area.
\end{abstract}

Armand Guta, PhD, associate professor, Faculty of the Foreign Languages and Literatures - Department of Russian and Slavic Philology, University of Bucharest; Institute of Ethnography and Folklore in Bucharest, Romania, e-mail: aeliuariort274@gmail.com

Key words: Central European immaterial culture, ancient Vlach influences, Central Slavic and Romanic cultural symbiosis.

DOI: http://dx.doi.org/10.14746/bp.2015.22.6

Concerning revealing the ancient role of Vlach musical heritage within Slovak and Czech musical tradition during our research in Prague and Bratislava archives and libraries we have found several medieval documents about Vlach bagpipe players. All of these documents describe with accuracy the Vlach folkloric tradition especially when talking about playing bagpipes. The oldest Czech documents that confirm the tradition of bagpipe playing within theVlach pastoral communities comes from the 16th century on March 1576 when within the Rvačovski document there first appeared the name of Vavrinec Leander and one year later in 1577 the same histo- 
ric source talks about Jenicku from Krizce Zlato (Olomunec) who sang very well with the bagpipes.

In the same document many activities such as singing with a bagpipe or dulcimer has been attributed only to the Vlach performers and in which we can even find even a description of one of these Vlachs through a vivid portrait: "He is a tall and a stout man as other many shepherds who live on whole Carpathian range mountains are until the Moravian region". In the Rvčaovskieho document there is a complete description of a very tall and stout Vlach who visited a town: "he was like a shepherd among noisy cattle which seems to migrate without the cow herder. He cannot understand this way of life so he quickly drives to his herd up in the mountains on the green pasture because only there he can find peace". The Rvačovski Chronicle show us even the Vlach shepherd's gesticulated behaviour because this type of skill is specific only for the Vlachs who know how to play the bagpipes well. He was a very strong and handsome man with broad shoulders and a massive torso like an ox, with brown eyes and black hair completed by full red lips and white teeth. When he blew air into his bagpipe instrument to play we could observe that all his muscles were contracted like several twisting snakes`»" .

We have also to mention the name of Jiska Remurka from Jirostarovy on Psohlovic because "this man plays like an angel so when he performs his creation in front of people or nature itself then even wild animals kneel in front of him listening motionless to his performance". In the same manuscript entitled Rvačovski we can find very interesting information about seven to nine bagpipe players that were living in the second half of the 16th century in North Morava near Hana far away on the Western side of the Podhorocko between Boskovicu and Morava Trebovan. From the first half of the 17th century local Moravian documents certify the bagpipe playing as a tradition that was considered to be one of the specific Vlach traditions ${ }^{2}$. But one of the most important references refers to a man named Tomas Ovčarski who caught and slaughtered many lambs from the local nobleman's flock only with the intention to make several bagpipes out of them. This is the oldest Czech document which certifies Vlach bagpipe making from lamb skin ${ }^{3}$.

Another mention of the Vlach communities was a letter by the Catholic Bishop of the town of Hukvald sent to the Spanish count de Fuentis in which he promised the Spanish noble that will give him ten or more brave and skilful Vlachmen as protection against robbers during his journey to Prague. Two days later eight strong men arrived at the Bishop's residence and for three days they entertained the local nobility and their guests with their bagpipes and dulcimers showing their musical talents and skilful playing techniques through many beautiful songs. We have found one of the last mentioned Vlach fiddlers in the manuscript of Michail Praetorius that refers to

\footnotetext{
${ }^{1}$ Karol Vetterl, "Najstari zapravi o gajdoscu a valasski", Česki Lid 49, 1(1963): 269-274.

${ }^{2} \mathrm{~K}$. Vetterl, 270.

${ }^{3}$ K. Vetterl, 273.
} 
a well-known Vlach bagpipe player called Jan Kasian from Vsetin. Although this note is about a band of six fiddlers and bagpipers who played in the town of Vsetin between 1618 and 1620 and they were much esteemed because of their musical skills both by the rich and poor audiences alike ${ }^{4}$.

It is interesting to note that the discovery and studying of the folkloric creations considered to be the spirituality essence of a nation started in 1818 in Poland, in 1838 in Czech, but in the Slovak Republic after 1850, although before these dates there were several local folklorists who collected songs and customs. Slovak folklorists were puzzled by the few endemic particularities of this genre and folkloric types performed within the isolated rural communities from the Tatra Mountains. At first sight they were very surprised by the name (valassko) attributed to the genre and folkloric types, then by the style, type, tempo and the moment of interpretation for some songs, dances and customs. Based only on local memory and upon some historic sources Slovak musicologists have started investigating these strange folkloric creations. Beginning from 1894 when Leoš Janacek was the first researcher of Slovak folklore from the regions inhabited by the former Vlachs as: Hana, Walachia, and Slovakča Morava. He travelled on foot to many isolated regions searching this particular type of folklore. After researching for more than 30 years the folklore in Slovacia, Leoš Janacek was invited on 19th July 1925, to participate in the Valašski rok [Vlachs Festival], from Rožnov pod Radhnoštem, were he was really fascinated by the beauty, rhythm and style of the Vlach dance called odmeze [bătuta] performed by Rudolf Londin and Karol Langer from Vsetin.

Concerning the Romanian influences within Slovak folklore, these patterns were studied by Otto Elschekov one of the best ethnomusicologists who started his research in 1977 and who published his work from several folkloric collections in which he made reference to the old folklore collections made by Hugolin Gavlovic, a school master from the local Vlach school (1755), but at the same time Elschekov underlined the huge contribution of Jan Bruk between 1790 and 1798 when he gathered more than 100 popular songs in which there is a mention of the ethno name of Villach's or the reference to their performing qualities.

One of the songs the text spoke about was by a Vlach shepherd in this manner:

The shepherd plays from a whistle, And a Vlach plays from a caval,

The Drummer plays his drum,

On the trumpet plays another Vlach,

All of the people were having fun when they are listening to the music ${ }^{5}$.

\footnotetext{
${ }^{4} \mathrm{~K}$. Vetterl, 274.

${ }^{5}$ Otto Elschek, Slovenske ludove pištaly, Bratislava, 1977, p. 117.
} 
In this book Elschekov wrote about Vlach musical traditional instruments: long and short whistle, three or six hole whistles, the bagpipe, a single or double stringed violin, a long whistle with a mouthpiece, similar to a modern clarinet.

In the Bratislava Folklore Archive there are numerous black and white photos taken between 1890 and 1930 in which there can be seen Round Dances, Male Dances or Vlach Weddings and also a black and white documentary film of about 18 minutes made by the Tatrafilm studio on 19 May 1925 in Roznov pod Radhoštem county in which we can see an old Vlach dance Orzacke[Military] performed before the male wedding group who are about to take the bride from her father's house.

In the photo collection Valašsko a Lašske spisske we can find a photograph taken in 1892 at a Vlach wedding party, in which one can observe without any doubt genuine Romanian traditional style costumes (similar to those from Transylvania, Bistrița-Năsăud county), but also the costumes and folkloric instruments of the music bands (tarafului) members, because all of the members were playing on instruments of South-East European origins (contrabass, bagpipes, whistles, violins, dulcimers).

In this book, O. Elschekbeside gives a brief and but beautiful description of the Vlach repertoire and 39 photos of all of the Vlach musical instruments. The author wrote about Vlach music: "Vlach shepherds folklore gives an artistic function of top quality pure instrumental linear musical structure through the strict control of the genre discovering a huge variety of variants and sub variants because all of these pieces of music express the amazing richness of the human spirit. The intimate link between the expressive qualities of the music, whatever is the performed genre, shows us the deep and meaningful representations of these musical creations, but even their ancient origins probably are from the Vlach one"6.

In 1991 the Slovak Choreographic Anthology was published by three Slovak musicologists M. Mazorova, Kl. Ondrejka and O. Elschek which contains 196 dances, together with music and the texts of male shouts, and of course the origins of the analysed musical repertoire. Before the apparition of this rare musical anthology we have to remember the book by K.Zdenek, where we can find 37 dances named Valašske tance $^{7}$ [the Vlach Dances]. Into this micro-anthology the dances are divided into four chapters: Tance tocive [Dances with precise movements], Skoki [Jumps], Figuralne I and Figuralne II [Dances with shouting and gestures]. All of the dances from the first chapter have the Vlach denomination: Valaška I, Valaška II, Valaška III, Obracani [Twist Dance], Zrtvanij [Axis Turning], Starovalasšky-valašky [Old Romanian], Hanačka [From Hana], Uherska-Slovenska-Valašky Čardas [Vlach-Romanian Ciardash]. In the second chapter we found three dances having clear Vlach origins: Odmezek [Tread], Zabski [Frog] şi Kravarska [Cow hander]. But all of the dances from the third chapter through the translation of their titles from Slovak into Romanian gives

\footnotetext{
${ }^{6}$ Elschek, Slovenske ludove pištaly, 118.

${ }^{7}$ Zdenek, Kaspar, f.a., Zahraj ne, hudecku, Valasske tance s rukopisnyh sberu Zdenka Kaspara), Bratislava, 1966.
} 
us proper answers about these dances: Shepherd dance, Under green forest, Crooked, Wheat, On the Mill, On the sheepfold, etc.," 8 . In the last two chapters we found dances of Slovak, Polish, Hungarian and Gypsy origins, but, we do not know the motifs why the author has included these types of dances within his collection. Probably, despite their actual denominations, these types of dances have an old Romanian origin.

Between 1900 and 2005 in Slovakia more than 70 historic and folkloric monographs of all Slovak villages and hamlets which were founded by Vlach shepherds have been published. In these historical and folkloric monographs were described Vlach customs and dances especially in the Almanach Valasske roku, Roznov pod Radhostem, Poradatelstvo Valasskeho roku [Vlach Almanac] and a second edition of this almanac dedicated to 75th anniversary of the museums existence ${ }^{9}$; Gajdu a gajdosska tradice na Valassku a Slovacku, Straznice: Krajske srediste lidoveho ume$n i$ [ the Bagpipe and its musical tradition] ${ }^{10} ; 700$ letValasske obce Kozlovice: sbornik clanu $k$ vyroci zalozeni obci, Kozlovice [700 years of Vlach Tradition] ${ }^{11}$; Valasska svatba na Narodnopisne vystave cehoslovanske v Praze [Vlach Wedding within Czechoslovak Folkloric creations] ${ }^{12}$; Etnograficky atlas Czech, Moravy a Slezska, vol. IV, Etnografsky a etnicky obraz Czech, Moravy a Slezska (1500-1900) narodnopisne oblasti kulturni arealy, etnicke a etnografske skupiny [Ethnographic Atlas of the Ethnic Image of Czechs, Moravians and Silesians (1500-1900) after Ethnic and Cultural Area Collections $]^{13}$, where we found a Christmas Carol that gives a description of the Vlach shepherds. This carol was sang by a group called Bethelmci and the members were: Fedor, Stacho (Stancho), Anjel, Bacia şi Kubo (he is the one wearing a leather sheep mask on his face and a costume made of bear fur)" "14. The carol ritual is performed into the owner's yard and brings up popular Slovak stereotypes concerning the Vlach population. We decided to not translate this fragment of the carol simply because the motif through translation would lose its spiritual humour.

Voly, voly, voly krasti,

Ne odem da ovce pasti;

Ovciarov ne budem,

Radsej na zboj pojdem, za suhaj;

\footnotetext{
${ }^{8}$ Kramolis, C., Almanach Valasske roku, Roznov pod Radhostem, Poradatelstvo Valasskeho roku, 1925, Roznov pod Radhostem.

${ }^{9}$ Rutta, Ludovic., Gajdu a gajdosska tradice na Valassku a Slovacku, Straznice: Krajske srediste lidoveho umeni, 1964, Bratislava.

${ }^{10}$ Bakala, J, Tabasek, O., Bohac, J., 700 let Valasske obce Kozlovice: sbornik clanu k vyroci zalozeni obci, Kozlovice, 1994, Obicni urad, Kozlovice.

${ }^{11}$ Urbancova, E., Valasska svatba na Narodnopisne vystave čehoslovenske v Praze, 1895, „Narodnopisna revue”, Prague (1995)5, 3: 136-139.

12 Jerabek, R., et al., Etnograficky atlas Czech, Moravy a Slezska, vol. IV, Etnografsky a etnicky obraz Czech, Moravy a Slezska (1500-1900) narodnopisne oblasti kulturni arealy, etnicke a etnografske skupiny, (Praha: Etnologicky ustav, 2004), 120-133.

13 Jerabek, R., et al., 124.

14 Jerabek, R., et al., 125-126.
} 


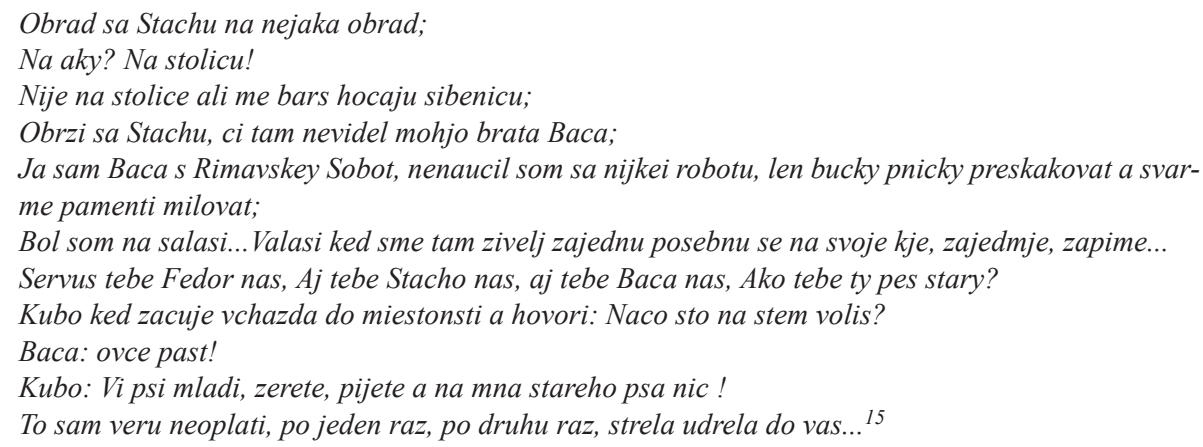

All Slovak and Czech folklore collections show us the particular interest and scientific purpose these very old and endemic musical creations of the Vlach population had during the many centuries of cohabiting within the Central Slavic nations. This scientific interest began after the First World War when many Slovak and Czech researchers identified and analysed all of the non-Slavic elements from several popular creations collected during the last century. Concerning Slovak and Czech scholars we can talk about a zonal particularity being generic," immaterial heritage of the Carpathian culture" whose specificities have yet much to offer us from the scientific point of view.

In our opinion the oldest scientific regional studies from Poland were made in 1818 by many historians, geographers and folklorists. These studies made reference only to those books we could find and research during our scientific stages as: Stanisław Staszic ${ }^{16}$, Aleksander Stadnicki ${ }^{17}$,Wincenty Pol ${ }^{18}$, Adolf Chybiński ${ }^{19}$, Seweryn Udziela ${ }^{20}$, Kazimierz Dobrowolski ${ }^{21}$, Zofia Holub-Pacewiczowa ${ }^{22}$, Stanisław

15 Jerabek, et al., 127-128.

16 Stanisław Staszic, O ziemiorodtzwie Karpatow i innych gor i rownin Polski [About the natural resources of the Carpathians and other mountains and plains Polish], Warszawa 1815.

17 Aleksander Stadnicki, $O$ wsiach tak zwanych wołoskich na pótnocnym stoku Karpat, Lwów 1848.

18 Wincenty Pol, Rzut oka na pótnocne stoki Karpat, Kraków 1851.

19 Adolf Chybinski, ,,Z dawnej pasterskiej poezji i muzyki górali podhalańskich”, [Something about Goral Shepherd Poetry and Old Music from Podhale], Wierchy, R. 1, (1923).

${ }^{20}$ Seweryn Udziela, „Górale od Żywca” [The Gorals from Żywiec], Wierchy, R. 2, (1924).

${ }^{21}$ Kazimierz Dobrowolski, Migracje wołoskie na ziemiach polskich [The Vlachs Migration into Polish Regions], Lwów 1930; K. Dobrowolski, „Studia nad kulturą pasterską w Karpatach północnych” [A Study into Carpathian Shepherd Culture], Wierchy, R. 29 (1960); K. Dobrowolski, „Kultura pasterska w Karpatach i na Bałkanach jako dziedzina międzynarodowej współpracy naukowej” [Carpathian and Balkan Shepherd Culture like an International Scientific and Cooperation Domain], Wierchy, R.28, (1959), p, 217-221.

22 Zofia Holub-Pacewiczowa, ,Z badań nad pasterstwem karpackim i alpejskim” [Another research about Carpathian and Shepherds of the Alps], Wierchy, R.8, (1930); Z. Holub-Pacewiczowa, Osadnictwo pasterskie $i$ wędrówki w Tatrach i na Podtatrzu [Shepherd Shelters and Fireplaces on the Tatry and Under the Tatry Mountains], Kraków, 1931. 
Leszczycki $^{23}$, Stanisław Mierczynski ${ }^{24}$, Anna Kutrzebianka ${ }^{25}$, Marian Gotkiewicz ${ }^{26}$, Stanisław Berezowski ${ }^{27}$.

Ioan Licea made between 1926 and 1927 a visit to Poland where he discussed with several scholars from Warsaw and Krakow the scientific Polish interest in Romanian traditional culture and its links with Carpathian immaterial cultural heritage After that he wrote a very interesting study: "The first Polish ethnographic monograph was made in 1811 by Ig. L. Czerwinski [Ignacy Lubicz Czerwiński, Okolica Zadniestrska między Stryjem i Łomnica, czyli opis ziemi i dawnych klęsk lub odmian tej okolicy; tudzież, jaki jest lud prosty dla religii i dla pana swego? Zgoła jaki on jest? W catym sposobie życia swego, lub w swych zabobonach albo zwyczajach, Lwów 1811]. Fifty years later Oskar Kolberg together with Jan Aleksander Karłowicz had collected a huge amount of ethnographic and folkloric material. In their opinions, stories have their most important place within Polish traditional literature. These stories were divided into several categories: myths, traditions and fairy tales. From the literary point of view the Polish scholars were considering them as being reminiscences from classic literature. After W. Fischer, Polish traditional poems number at more than 20,000. One of the best critical editions concerning Polish traditional poems together with a comparative study over other Slavic traditional poems was made by prof. I. St. Bystroń who classified these poems as: Christian songs, love songs, family songs, shepherd songs, hunting songs, heroic songs, military songs, political songs, and beggars songs, etc. But, in the poetry edition among many shepherd songs we can find one poem entitled: Woloszyn owce rozproszyt [the Vlach who had lost his sheep] from O. Kolberg's collection, discovered in Poznan. The song come together with a short note: "Syn (son) wałaszy or Wołoszyn, generally speaking they have a shepherd's name. The name comes from Romanian (od Wołochów) when under their presence sheepherding flourished and spread far away until Western Europe, where even today there is a mountain population named Wołoch, in Czech (Polish) Silesia"28.

In July 2011 we did some research into folklore and ethnographic phenomenon within four Polish villages starting from the village of Koniaków until the PolishSlovak border. The research was focused on the narrative categories of the contemporary folklore, accounts about life experiences, and certain events such as:

a. Personal tales (family narratives, melted in autobiographies, portraits);

b. Orally histories (village story);

23 Stanisław Leszczycki, ,Szałasy kamienne w Beskidzie Małym” [Stone dwellings from the Small Beskids], Wierchy, R.10, (1932).

24 Stanisław Mierczyński,"Muzyka podhalańska" [Music from Podhale], Wierchy, R. 10, (1932).

25 Anna Kutrzebianka, ,Życie pasterzy w paśmie babiogórskim” [The Everyday life of a Shepherds group within Babiogorski Stories], Gronie, R. 1 (1938) no 2, p. 50-55-

26 Marian Gotkiewicz, „O tzw. Wołochach na Słowacji” [Something about the So Called Vlachs from the Slovak Republic], Wierchy, R.20, (1950-1951).

27 Stanisław Berezowski, "Problemy geograficzne pasterstwa wędrownego" [Some Problems of Human Geography about Transhumant Communities] in: Pasterswo Tatr Polskich i Podhala [Shepherds from the Polish Tatry and Podhale], 1, Wroclaw, 1959.

${ }^{28}$ Ion Licea, Prin Polonia. Insemnari fugare [Through Poland. Short Notes], (Iaşi, 1927), 45-46. 
c. Orally diary (about the festival history);

d. Memories;

e. History and Legends.

The nucleus of these narrative structures have been generated by events from the past. The referential frame of these texts belongs to the traditional collective memory. Storytelling aims at shaping the individual and group personalities. Only in the colloquial context, the local idiom góralski transmitted orally means (put in value) through narratives built on a popular style and the private context belongs to the older generation. Their memories are comprised of life experience, narrative identities being related to the teller's individuality (age, experience, life), which synthesizes the local representations of the community. In the system of customs we can notice an accelerated movement of the process which leads to the disappearance, transforming or renewal of the components. The Góral rural milieu from Polish was strongly influenced by the religious, political and historical conditions of the times and today it is influenced by contemporary life, and it has transformed from an autarchic society into a consumption one, in a few decades. Implicitly, innovation was stronger than tradition. These general tendencies of folklore are reflected by the decline of the local traditional repertoire of tales and legends, the maintaining of calendar and family (births, weddings and funerals) traditional customs and the strength of instrumental music as compared to vocal music. Some of these features also characterize the local traditions of all of the Carpathian communities. The passing of rituals and calendar customs are still present but with multiple changes and adjustments.

Thus, genuine folklore should be considered apart from "consumption" folkloric forms, the latter being presented at shows, festivals, tourism or as a commodity, and having different functions considering its performance outside the context in which it was created. In the second part we analysed some of the customs and traditions which are still active in the researched communities, categorized according to the calendar cycle (adult carolling and to the customs integrated within the family cycle like weddings and funerals). Nowadays realities indicate that some folkloric genres and types are still maintained and preserved showing a different communitarian attitude towards the importance given to the respective circumstance. The fact that folkloric tradition was not evident in the above-mentioned period caused the disappearance or simplification of some elements. Thus, its dominant functions are entertainment and reaffirming at the same time the local identity. The dynamic of this custom raises the issue of the significance and importance of the creative act at the level of the reconstruction of male dance, which was put into circulation by the nowadays Goral tradition or ancient Vlach basic motifs, slightly modified, together with several Gorals from Poland and the Vlachs folkloric groups from Slovakia and Czech Republic in a well know annual festival named Troje Meze that starts in the last week of June or in the first week of July.

During 1970-1999 we observed a general scientific and cultural interest that doubled by financial efforts concerning collecting and publishing Polish Mountaineers folklore, because they had published almost 73 traditional musical albums by Górals 
within the Podhale, Beskids and Silesia counties, and between these albums we have found 16 albums of traditional choreology.

We want to underline the several projects made by the Institute of Archaeology and Ethnology from Kraków and of course all the seminars dedicated to Carpathian ethnology, because scientific interest is still actual in the Academic Polish milieu. In all of these studies published in the last few years in Poland we have discovered clues, scientific documents, opinions that lead us to a shyness but proper acceptance of historic realities that obviously show the presence and ethno-cultural contributions of Vlach shepherds to the completion of the Central European cultural spirit of our Carpathian neighbours.

This short paper has presented a reasoned argument on a particular issue. We hope that our study has succeeded in outlining some important benefits in scientific knowledge of what Central Slavic scholars think about the origins of so called Vlachs or Vlachs and how they treated this population within their studies.

In conclusion, I believe it is clear that there are huge benefits to be gained from reading between the lines of several medieval or modern historic Central Slavic documents. I would even go so far as to say that it should be compulsory for all scholars to rethink more profoundly these issues, because the benefits that it will bring with this type of reinterpretation for today in researching in general are too great to be ignored.

Because the main motto of the European Union is "Unity in diversity" and Romania and all Central European countries are members with full rights we think that the European cultural milieu will be improved with these studies about old folklore Vlach heritage into traditional culture. At the end of the day we can say that in all scientific and cultural milieu hangs overwhelming responsibilities concerning, tolerance, understanding and constructive dialogues. 
